\title{
Thermodynamic Analysis of a Renewable Energy-Driven Electric Vehicle Charging Station with On-Site Electricity Generation from Hydrogen and Ammonia Fuel Cells
}

\author{
Yusuf Bicer \\ 0000-0003-4753-7764 \\ Division of Sustainable Development (DSD), College of Science and Engineering (CSE), Hamad Bin Khalifa University (HBKU), Qatar \\ Foundation $(Q F)$, Education City, Doha, Qatar
}

\begin{abstract}
The vast implementation of electric vehicles (EVs) greatly depends on developing sustainable and green EV charging stations. This study proposes to develop and assess an off-grid and renewable energy-driven EV charging station, which is hybridized with hydrogen and ammonia fuel cells. Chemical energies of hydrogen and ammonia are stored in the storage tanks to be used in the hydrogen and ammonia fuel cells. The designed hybrid system is capable of storing energy in the chemical form when there is excess production. Ammonia is stored in liquid form rather than gaseous form, which reduces the storage tank capacity considerably and decreases the losses. The designed system, which includes a wind turbine, concentrated photovoltaic (CPV) and fuel cells, can produce about 1.1 MW of power and $15.46 \mathrm{MWh}$ of electricity in a single day, corresponding to about 294 number of EVs. In addition, the hybrid system can charge up to 644 EVs if the ammonia feed rate is increased to $0.1 \mathrm{~kg} / \mathrm{s}$. The fuel cells are capable of generating about $80 \%$ of the charging station. The effects of important key parameters such as wind speed, solar irradiance and fuel supply rates are investigated to observe the impacts on the overall system.
\end{abstract}

Keywords: Electric vehicle; Energy storage; Solar energy; Thermodynamics, Wind energy
* Corresponding author

Yusuf Bicer

ybicer@hbku.edu.qa

Address: Division of Sustainable Development (DSD), College of Science and Engineering (CSE), Hamad Bin Khalifa University (HBKU), Qatar Foundation (QF), Education City, Doha, Qatar

Tel:+97444542906

Research Article

Manuscript

Received $\quad 18.06 .2020$

Revised $\quad 30.07 .2020$

Accepted 23.08.2020

Doi: 10.30939/ijastech..754580

\section{Introduction}

The increasing demand for cleaner transportation means make the electric vehicle (EV) industry innovative to find alternative solutions. It is reported in the literature [1] that if the EVs or Plug-in Electric Vehicle (PHEV) are charged from conventional energy sources, they are still pollutant in the whole life cycle. It is similar in the cases where they are charged by the grid mix where most of the electricity comes from fossil fuel sources [1]. As the electricity is typically produced from fossil fuel combustion such as natural gas and coal [2], there is a concern on the expansion of EVs if the power production trend remains the same [3]. Electricity production is the most vital sector accountable for high GHG emissions including $\mathrm{CO} 2$, which affected numerous clear weather changes worldwide, causing numerous natural disasters affecting every day millions of people's lives [2].

The transportation sector is one of the dominant energyconsuming segment and will continue to increase by about $54 \%$ until 2035 [4]. Since fossil fuel derived, gasoline and diesel, are the main sources for vehicles, the expected emissions are significantly high if there will be no green solutions such as renewable driven-EV/PHEV charging stations [5]. In case the world continues using these fossil fuels, the depletion of fossils will rise and the greenhouse gases (GHG) emissions will pollute the environment considerably causing global warming $[6,7]$. Especially in urban places, road transportation is the fundamental reason of environmental contamination [8]. The reports showed that more than half of the produced oil is consumed by the transport sector causing almost 6,892 Mt CO2 emissions of $\mathrm{CO} 2$ [9], which yielded the second largest emitting sector [2]. Therefore, the high reliance on fossil derivatives causes several ecological issues as well as climate change and economic consequences [10]. As a solution, several counties attempt to substitute conventional vehicles with EVs/PHEVs or other alternative fueled vehicles such as hydrogen, ammonia, natural gas etc. [11, 12]. The implementation of EVs has risen drastically in recent years in the world [13], where there were about 1.04 million EV sales in the year 2017 [14]. 


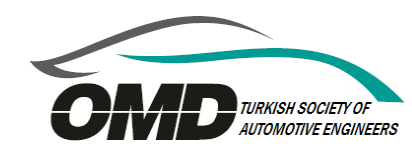

There are other issues related to EV infrastructure related to power networks. Normally, EV charging takes a very long time unless there are fast-charging stations available on the streets. Hence, it is desired to install fast-charging stations throughout the city. Considering thousands of EVs are charged at the same time via fast-chargers, there occurs a great stress on the power grid, which can cause intermittency or failure. It will also affect the overall electricity distribution structure [5] because there will be a sudden high demand causing an overloaded [15]. Henceforth, there are many studies focusing on how to overcome this type of problem in the literature [10]. This is one of the main aspects of proposing a stand-alone charging station as in this study.

There are a couple of studies in the literature focusing on hydrogen in which the generated electrical energy was from grid-independent renewable energy sources such as solar PVs and wind turbines [16]. In addition, the fuel cells are also employed to overcome the intermittency issue of renewables such as solar and wind [3]. Hence, the hybridization of several energy production methods bring more sustainable and reliable operations. For instance, solar and wind energy systems were hybridized along with hydrogen [16] but there was a battery bank for storing the electricity. In that case, the electricity was supplied to an electrolyzer to generate hydrogen. After that, hydrogen is stored in the tanks and used in the fuel cells for electricity generation. Another study investigated a multigeneration system providing heating, cooling and electricity supply for buildings with an EV charging station [17]. Therefore, it is obvious that there is a need to design, develop and assess off-grid, renewable driven, hybrid fuel cell-based EV charging stations to make EV implementation more environmentally friendly and sustainable.

In the current study, on-site production of hydrogen or ammonia is not considered because these processes require intensive energy, which reduces the total energy generation, hence the number of EVs/PHEVs that can be charged. The specific objectives of this study are listed as follows:

- To design an off-grid EV/PHEV charging station with hybrid renewables and fuel cells

- To introduce on-site $\mathrm{H}_{2}$ and $\mathrm{NH}_{3}$ storage for operating the fuel cells

- To calculate the amount of energy generation from each subsystem and number of EVs that can be charged in a day

- To analyze the designed hybrid system in terms of thermodynamic performance

- To investigate the effects of several key parameters such as solar irradiance, wind speed and fuel feed rate on the overall system performance

\section{System description}

The designed system is a standalone renewable energydriven EV/PHEV charging station capable of generating onsite electricity. It is noted that since PHEVs also need charging from an electrical sources, the designed system can serve to PHEV as well. Moreover, when the future mix transportation systems are considered, the hydrogen fuel cell vehicles (HFCVs) and ammonia fuel cell vehicles (AFCV) can also utilize this type of charging station once the pumping unit arrangements are made from the storage tanks.

The schematic diagram of the designed hybrid system for EV charging stations is shown in Fig. 1. The main inputs required to operate the hybridized system are solar energy and wind energy as well as chemicals $\left(\mathrm{H}_{2}, \mathrm{O}_{2}, \mathrm{NH}_{3}\right)$. The system does not produce these chemicals on-site but rather utilizes the transported chemicals on-site through fuel cells. The CPVs and fuel cells are capable of generating DC electricity, which is needed for EV/PHEV battery charging. However, the wind turbine generates AC electricity, which is later on converted into DC via a converter.

The CPV is preferred because they have higher electrical efficiency and lower area requirement compared to PVs. The wind turbine is selected with a lower hub height and smaller rotor diameter to make the integration easier. $\mathrm{NH}_{3}$ can be stored longer periods of time compared to $\mathrm{H}_{2}$ due to its thermo-physical characteristics. For fuel cells to operate by converting chemical energy into electrical energy, both fuel and oxygen are required simultaneously. Therefore, the $\mathrm{O}_{2}$, $\mathrm{NH}_{3}$ and $\mathrm{H}_{2}$ gases are stored separately in the storage tanks. However, it is noted that they can also run on air, which can eliminate the oxygen storage tank.

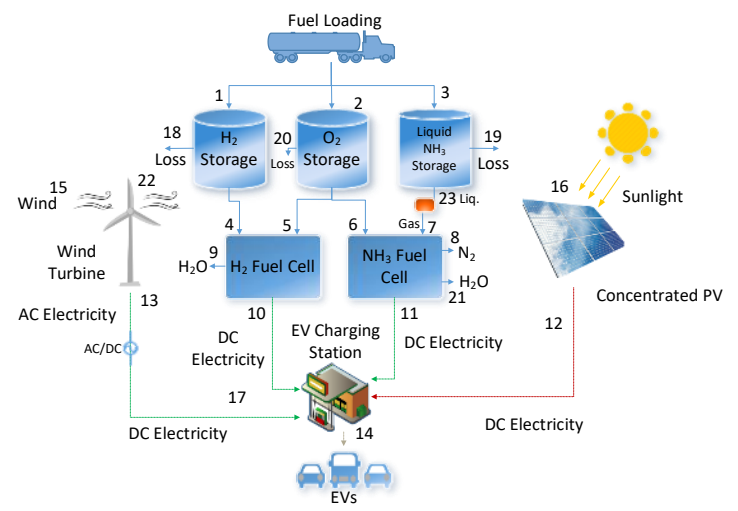

Fig. 1. Overall system diagram with on-site power generation from $\mathrm{H}_{2}$ and $\mathrm{NH}_{3}$ fuel cells, $\mathrm{CPV}$ and wind turbine for EV/PHEV charging stations

The $\mathrm{H}_{2}$ and $\mathrm{O}_{2}$ are stored in gaseous form whereas the $\mathrm{NH}_{3}$ is stored in liquid form. However, before entering the fuel cell, $\mathrm{NH}_{3}$ is evaporated through natural air circulation (since the ambient temperature is higher than the storage temperature). The liquid form storage saves considerable space due to quite high density. The product of $\mathrm{H}_{2}$ fuel cell is water, hence the produced water can be later used in auxiliary equipment of the charging station. The products of $\mathrm{NH}_{3}$ fuel cells are $\mathrm{N}_{2}$ and water. This means that the overall system does not emit any GHG in contrast to grid-tied charging stations. Ammonia, which is stored in the tank, is converted into electricity through $\mathrm{NH}_{3}$ fuel cell for charging EVs/PHEVs.

The proposed is initially proposed to be grid-independent 
due to several reasons mentioned in the introduction section such as extreme sudden load on the grid due to fast-charging and emissions coming from the grid mix. However, the system can be also grid-tied if needed to enable electricity trading. In that case, such a stand-alone system will bear less burden on the national grid with more flexibility of providing electricity from chemical methods via fuel cells.

\subsection{Operation Methodology}

Since there are chemical energy storage units within the EV/HEV charging station, the fuel cells can be enabled only when necessary, which can solve the excess electricity issue. Therefore, during the day time, the priority is given to the CPV unit, and then to the wind turbine. The detailed priority scheme for the operation of the proposed hybrid system is as follows:

- The CPV unit generates DC power only during day time, hence it is used directly during day times to charge the $\mathrm{PEV} / \mathrm{HEV}$ s. Under maximum irradiation of 1000 $\mathrm{W} / \mathrm{m}^{2}$, the CPV unit is desired to produce about $350 \mathrm{~kW}$ as threshold. However, the average value of $800 \mathrm{~W} / \mathrm{m}^{2}$ is used in the analysis.

- In order to provide supplementary power needed for fast charging stations, the power generated by wind turbines will be important to sustain the electricity supply. The wind turbine capacity at around $11 \mathrm{~m} / \mathrm{s}$ is about $420 \mathrm{~kW}$ $\mathrm{AC}$ as a higher threshold value. Nevertheless, this wind speed is not common in many areas, therefore, the average wind speed of $6.5 \mathrm{~m} / \mathrm{s}$ is used in the analysis to reflect the normal operations.

- $\quad$ Since there are limitations of area and place within a charging station, the allocated wind turbine and CPV capacities are not large. This is compensated by the chemicals storage, which will occupy less volume and can be placed underground. The

- The intermittent nature of the solar and wind energy is overcome by using on-site hydrogen and ammonia storage and fuel cells, acting as a back-up power. The nominal capacity of $\mathrm{H}_{2}$ and $\mathrm{NH}_{3}$ fuel cells are desired to be $425 \mathrm{~kW}$ and $350 \mathrm{~kW}$, respectively. However, they can be operated at different loads depending on the demand of EVs/HEVs. During the analysis, they are run continuously to simulate the performance of the complete system under full load conditions. Majority of power is produced by fuel cells as they are capable of providing more stable electricity to the charging units. This allows to charge more vehicles per day

\section{Analyses}

The thermodynamic analysis of the off-grid EV charging station with on-site power generation is based on the following assumptions:

- Steady-state steady flow operations exist for all components.

- $\quad$ Reference pressure and temperature are taken as 101.3 $\mathrm{kPa}$ and $25^{\circ} \mathrm{C}$, respectively.
- $\quad$ Kinetic and potential terms are neglected for all components except the wind turbine [18].

- The average sun irradiance intensity is taken as 800 $\mathrm{W} / \mathrm{m}^{2}$ with an average sunny hours of 8 .

- The temperature of the sun surface is taken as $5777^{\circ} \mathrm{C}$.

- The wind turbine transmission and generator efficiencies are 95\% [19].

- AC-DC conversion efficiency is considered as 95\% [20].

- The charging station efficiency is taken as $95 \%$ accounting the EV battery charging and discharging phases.

- The single battery capacity of an EV is taken as $50 \mathrm{kWh}$.

The thermodynamic analysis approach followed in this study is based on writing the balance equations for mass, energy, entropy, and exergy for all subsystems and overall system. In addition, to quantify the performances of the subsystems and overall system, the energy and exergy efficiencies are defined and calculated. The model is constructed in Engineering Equation Solver (EES) [21] for the overall system. The enthalpy values include the lower heating value (LHV) of the fuel elements $\left(\mathrm{H}_{2}\right.$ and $\left.\mathrm{NH}_{3}\right)$ whereas the chemical exergy content of all elements $\left(\mathrm{N}_{2}, \mathrm{H}_{2}, \mathrm{O}_{2}, \mathrm{NH}_{3}\right)$ are taken into account.

In the following section, the governing equations for each subsystem and overall system are given in detail.

\section{$\mathrm{O}_{2}$ Storage}

The energy balance equation (EBE) of $\mathrm{O}_{2}$ storage unit can be expressed as follows:

$$
\begin{aligned}
& \dot{\boldsymbol{m}}_{\mathrm{O}_{2}, 2} \cdot \boldsymbol{h}_{\mathrm{O}_{2}, 2} \\
& \dot{\boldsymbol{m}}_{\mathrm{O}_{2}, 6} \boldsymbol{h}_{\mathrm{O}_{2}, 6}
\end{aligned} \dot{\boldsymbol{m}}_{\mathrm{O}_{2}, 20} \cdot \boldsymbol{h}_{\mathrm{O}_{2}, 20}+\dot{\boldsymbol{m}}_{\mathrm{O}_{2}, 5} \cdot \boldsymbol{h}_{\mathrm{O}_{2}, 5}+
$$

Here, the mass loss is assumed to be $6 \%$ of total mass due to boil-off gas, permeation, and leakage.

The entropy balance equation $(\mathrm{EnBE})$ of $\mathrm{O}_{2}$ storage unit can be expressed as follows:

$$
\begin{aligned}
& \dot{m}_{O_{2}, 2} \cdot s_{O_{2}, 2}+\dot{S}_{g^{2} n_{O_{2}}}{ }_{\text {storage }} \\
& \dot{m}_{O_{2}, 5} \cdot s_{O_{2}, 5}+\dot{m}_{O_{2}, 6} s_{O_{2}, 6}
\end{aligned}
$$

The exergy balance equation $(\mathrm{ExBE})$ of $\mathrm{O}_{2}$ storage unit can be expressed as follows:

$$
\begin{aligned}
& \dot{m}_{O_{2}, 2} \cdot e x_{O_{2}, 2}=\dot{m}_{O_{2}, 20} \cdot e x_{o_{2}, 20}+\dot{m}_{o_{2}, 5} \cdot e x_{o_{2}, 5}+ \\
& \dot{m}_{\mathrm{O}_{2}, 6} \cdot \boldsymbol{e x}_{\mathrm{O}_{2}, 6}+\dot{E} x_{d, O_{2}} \text { storage }
\end{aligned}
$$

The energy efficiency of $\mathrm{O}_{2}$ storage is written as follows:

$$
\eta_{\text {en }_{O_{2}} \text { storage }}=\frac{\dot{m}_{O_{2}, 5} \cdot h_{O_{2,5}}+\dot{m}_{O_{2}, 6} h_{O_{2,6}}}{\dot{m}_{O_{2}, 2} \cdot h_{O_{2}, 2}}
$$

The exergy efficiency of $\mathrm{O}_{2}$ storage is written as follows:

$\eta_{\text {ex }_{O_{2}} \text { storage }}=\frac{\dot{m}_{O_{2}, 5} \cdot e_{O_{2,5}}+\dot{m}_{O_{2}, 6} \cdot e x_{O_{2}, 6}}{\dot{m}_{O_{2}, 2} \cdot \operatorname{ex}_{O_{2,2}}}$

\section{H2 Storage}

The energy balance equation (EBE) of $\mathrm{H}_{2}$ storage unit can 
be expressed as follows:

$\dot{m}_{H_{2}, 1} \cdot h_{H_{2}, 1}=\dot{m}_{H_{2}, 4} \cdot h_{H_{2}, 4}+\dot{m}_{H_{2}, 18} \cdot h_{H_{2}, 18}$

where the mass loss $\left(\dot{\boldsymbol{m}}_{\boldsymbol{H}_{\mathbf{2}}, \mathbf{1 8}}\right)$ is assumed to be $10 \%$ of total mass. These losses occur mainly due to boil-off gas, permeation, leakage and cooling during gas compression [2224]. This number is taken from technical system targets set by U.S. DRIVE (Driving Research and Innovation for Vehicle efficiency and Energy sustainability) [25] where boil-off loss target is mentioned to be $10 \%$.

The entropy balance equation (EnBE) of $\mathrm{H}_{2}$ storage unit can be expressed as follows:

$\dot{m}_{H_{2}, 1} \cdot s_{H_{2}, 1}+\dot{S}_{g^{2} n_{H_{2}} \text { storage }}=\dot{m}_{H_{2}, 4} \cdot s_{H_{2}, 4}+$
$\dot{m}_{H_{2}, 18} \cdot s_{H_{2}, 18}$

The exergy balance equation $(\mathrm{ExBE})$ of $\mathrm{H}_{2}$ storage unit can be expressed as follows:

$\dot{m}_{H_{2}, 1} \cdot e x_{H_{2}, 1}=\dot{m}_{H_{2}, 4} \cdot e x_{H_{2}, 4}+\dot{m}_{H_{2}, 18} \cdot e x_{H_{2}, 18}+$

$\dot{E} \boldsymbol{x}_{d, H_{2} \text { storage }}$

The energy efficiency of $\mathrm{H}_{2}$ storage is written as follows:

$\eta_{\text {en }_{H_{2}} \text { Storage }}=\frac{\dot{m}_{\mathrm{H}_{2}, 4} \cdot h_{H_{2}, 4}}{\dot{m}_{\mathrm{H}_{2}, 1} \cdot h_{H_{2}, 1}}$

The exergy efficiency of $\mathrm{H}_{2}$ storage is written as follows:

$\eta_{\text {ex }_{H_{2} \text { Storage }}}=\frac{\dot{m}_{H_{2}, 4} \cdot \operatorname{ex}_{H_{2}, 4}}{\dot{m}_{H_{2}, 1} \cdot \operatorname{ex}_{H_{2}, 1}}$

\section{$\mathrm{NH}_{3}$ Storage}

The energy balance equation (EBE) of $\mathrm{NH}_{3}$ storage unit can be expressed as follows:

$\dot{m}_{\mathrm{NH}_{3}, 3} \cdot h_{\mathrm{NH}_{3}, 3}=\dot{m}_{\mathrm{NH}_{3}, \mathrm{7}} \cdot h_{\mathrm{NH}_{3}, 7}+\dot{\boldsymbol{m}}_{\mathrm{NH}_{3}, 19} \cdot h_{\mathrm{NH}_{3}, 19}(11)$

where the mass loss is assumed to be $7.5 \%$ of the total mass which occur mainly due to liquid ammonia storage causing boil-off gas in addition to permeation and leakage.

The entropy balance equation (EnBE) of $\mathrm{NH}_{3}$ storage unit can be expressed as follows:

$\dot{m}_{\mathrm{NH}_{3}, 3} \cdot s_{\mathrm{NH}_{3}, 3}+\dot{S}_{g e n}=\dot{m}_{\mathrm{NH}_{3}, 7} \cdot s_{\mathrm{NH}_{3}, 7}+$

$\dot{m}_{\mathrm{NH}_{3}, 19} \cdot s_{\mathrm{NH}_{3}, 19}$

The exergy balance equation (ExBE) of $\mathrm{NH}_{3}$ storage unit can be expressed as follows:

$\dot{m}_{\mathrm{NH}_{3}, 3} \cdot e x_{\mathrm{NH}_{3}, 3}=\dot{m}_{\mathrm{NH}_{3}, 7} \cdot \operatorname{ex}_{\mathrm{NH}_{3}, 7}+$

$\dot{m}_{\mathrm{NH}_{3}, 19} \cdot e x_{\mathrm{NH}_{3}, 19}+\dot{E} x_{d, \mathrm{NH}_{3} \text { storage }}$

The energy efficiency of $\mathrm{NH}_{3}$ storage is written as follows:

$\eta_{\text {en }_{N_{3}}{ }_{\text {storage }}}=\frac{\dot{m}_{\mathrm{NH}_{3}, 7} \cdot h_{\mathrm{NH}_{3}, 7}}{\dot{m}_{\mathrm{NH}_{3}, 3} \cdot h_{\mathrm{NH}_{3}, 3}}$

The exergy efficiency of $\mathrm{NH}_{3}$ storage is written as follows:

$\eta_{\text {ex }_{\mathrm{NH}_{3} \text { Storage }}}=\frac{\dot{m}_{\mathrm{NH}_{3}, 7} \cdot \operatorname{ex}_{\mathrm{NH}_{3}, 7}}{\dot{m}_{\mathrm{NH}_{3}, 3} \cdot \operatorname{ex}_{\mathrm{NH}_{3}, 3}}$

\section{$\mathrm{H}_{2}$ Fuel Cell}

The energy balance equation (EBE) of $\mathrm{H}_{2}$ fuel cell can be expressed as follows:

$\dot{m}_{\mathrm{H}_{2}, 4} \cdot h_{\mathrm{H}_{2}, 4}+\dot{\boldsymbol{m}}_{\mathrm{O}_{2,5},} \cdot \boldsymbol{h}_{\mathrm{O}_{2,5}}=\dot{\boldsymbol{m}}_{\mathrm{H}_{2} \mathrm{O}, 9} \cdot \boldsymbol{h}_{\mathrm{H}_{2} \mathrm{O}, 9}+$

$\dot{W}_{\mathrm{H}_{2} \mathrm{FC}, 10}+\dot{Q}_{\mathrm{H}_{2} \mathrm{FC}}$

The entropy balance equation (EnBE) of $\mathrm{H}_{2}$ fuel cell can be expressed as follows:

$\dot{m}_{\mathrm{H}_{2}, 4} \cdot s_{\mathrm{H}_{2}, \mathrm{in}}+\dot{m}_{\mathrm{O}_{2}, 5} \cdot s_{\mathrm{O}_{2}, 5}+\dot{S}_{g_{e n_{H_{2}} \mathrm{FC}}}=$

$\dot{m}_{\mathrm{H}_{2} \mathrm{O}, 9} \cdot S_{\mathrm{H}_{2} \mathrm{O}, 9}+\frac{\dot{Q}_{\mathrm{H}_{2} F C}}{T_{b}}$

Here, the heat output is taken as $30 \%$ of the work output based on existing fuel cell efficiencies.

The exergy balance equation (ExBE) of $\mathrm{H}_{2}$ fuel cell can be expressed as follows:

$\dot{m}_{\mathrm{H}_{2}, 4} \cdot e x_{\mathrm{H}_{2}, 4}+\dot{m}_{\mathrm{O}_{2,5}} \cdot e x_{\mathrm{O}_{2,5}}=\dot{m}_{\mathrm{H}_{2} \mathrm{O}, 9} \cdot \operatorname{ex}_{\mathrm{H}_{2} \mathrm{O}, 9}+$

$\dot{W}_{\mathrm{H}_{2} F C, 10}+\dot{Q}_{\mathrm{H}_{2} F C}\left(1-\frac{T_{0}}{T}\right)+\dot{E x}_{d, \mathrm{H}_{2} F C}$

The energy efficiency of $\mathrm{H}_{2}$ fuel cell is written as follows:

$\eta_{e n_{H_{2} F C}}=\frac{\dot{W}_{H_{2} F C, 10}}{\dot{m}_{H_{2}, 4} \cdot L H V_{H_{2}}+\dot{m}_{O_{2}, 5} \cdot h_{O_{2}, 5}}$

The exergy efficiency of $\mathrm{H}_{2}$ fuel cell is written as follows:

$\eta_{\operatorname{ex}_{\mathrm{H}_{2} \mathrm{FC}}}=\frac{\dot{W}_{\mathrm{H}_{2} F C, 10}}{\dot{m}_{\mathrm{H}_{2}, 4} \cdot \operatorname{ex}_{\mathrm{H}_{2}, 4}+\dot{m}_{\mathrm{O}_{2}, 5} \cdot \operatorname{ex}_{\mathrm{O}_{2}, 5}}$

Considering that fuel cell operates 16 hours daily, the total energy generated from $\mathrm{H}_{2}$ fuel cell is calculated:

$W_{H_{2} C_{\text {Energy }}}=\dot{W}_{H_{2} C_{10}}$ time $_{\mathrm{H}_{2} F C}$

\section{$\mathrm{NH}_{3}$ Fuel Cell}

The energy balance equation (EBE) of $\mathrm{NH}_{3}$ fuel cell can be expressed as follows:

$\dot{\boldsymbol{m}}_{\mathrm{NH}_{3}, 6} \cdot \boldsymbol{h}_{\mathrm{NH}_{3}, 6}+\dot{\boldsymbol{m}}_{\mathrm{O}_{2}, 7} \cdot \boldsymbol{h}_{\mathrm{O}_{2}, 7}=\dot{\boldsymbol{m}}_{\mathrm{N}_{2}, \mathrm{8}} \cdot \boldsymbol{h}_{\mathrm{N}_{2}, 8}+$

$\dot{m}_{\mathrm{H}_{2} \mathrm{O}, 21} \cdot h_{\mathrm{H}_{2} \mathrm{O}, 21}+\dot{W}_{\mathrm{NH}_{3} \mathrm{FC}, 11}+\dot{Q}_{\mathrm{NH}_{3} \mathrm{FC}}$

Here, the heat output is taken as $30 \%$ of the work output based on existing fuel cell efficiencies.

The entropy balance equation (EnBE) of $\mathrm{NH}_{3}$ fuel cell can be expressed as follows:

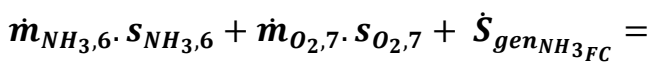

$\dot{m}_{N_{2}, 8} \cdot s_{N_{2}, 8}+\dot{m}_{H_{2} O, 21} \cdot s_{H_{2} O, 21}+\frac{\dot{Q}_{N_{3} F C}}{T_{b}}$

The exergy balance equation $(\mathrm{ExBE})$ of $\mathrm{NH}_{3}$ fuel cell can be expressed as follows:

$\dot{m}_{\mathrm{NH}_{3}, 6} \cdot \operatorname{ex}_{\mathrm{NH}_{3}, 6}+\dot{m}_{\mathrm{O}_{2}, 7} \cdot \operatorname{ex}_{\mathrm{O}_{2}, 7}=$

$\dot{m}_{N_{2}, 8} \cdot e \dot{x}_{N_{2}, 8}+m_{H_{2} O, 21} \cdot e x_{H_{2} O, 21}+\dot{W}_{N_{H} F C, 11}+$

$\dot{Q}_{\mathrm{NH}_{3} \mathrm{FC}}\left(1-\frac{T_{0}}{T_{b}}\right)+\dot{E} x_{d, N H_{3} F C}$ 
The energy efficiency of $\mathrm{NH}_{3}$ fuel cell is written as follows:

$\eta_{e n_{N H_{3}} F C}=\frac{\dot{W}_{N_{3} F C, 11}}{\dot{m}_{N_{3}, 6} \cdot h_{N H_{3}, 6}+\dot{m}_{O_{2}, 7} \cdot h_{O_{2}, 7}}$

The exergy efficiency of $\mathrm{NH}_{3}$ fuel cell is written as follows:

$\eta_{\text {ex }_{N H_{3}}}=\frac{\dot{W}_{\mathrm{NH}_{3} F C, 11}}{\dot{m}_{\mathrm{NH}_{3}, 6} \cdot \operatorname{ex}_{\mathrm{NH}_{3}, 6}+\dot{m}_{O_{2}, 7} \cdot \operatorname{ex}_{O_{2}, 7}}$

Considering that fuel cell operates 16 hours daily, the total energy generated from $\mathrm{NH}_{3}$ fuel cell is determined:

$W_{\mathrm{NH}_{3} \mathrm{FC}}=W_{\mathrm{NH}_{3} \mathrm{FC} C_{11}}$ time $_{\mathrm{NH}_{3} \mathrm{FC}}$

Wind Turbine

The energy balance equation (EBE) of the wind turbine can be expressed as follows:

$\dot{m}_{a i r, 15}\left(h_{a i r, 15}+\frac{v_{15}^{2}}{2}\right)=\dot{m}_{a i r, 22}\left(h_{a i r, 22}+\frac{v_{22}^{2}}{2}\right)+\dot{W}_{W T}$

Here, inlet velocity is taken as $6.5 \mathrm{~m} / \mathrm{s}$ with a wind turbine lambda $(\lambda)$ of 0.6 and the wind turbine rotor diameter is taken as 35 meters.

The entropy balance equation (EnBE) of wind turbine can be expressed as follows:

$\dot{m}_{a i r, 15} \cdot s_{a i r, 15}+\dot{S}_{g e n_{W T}}=\dot{m}_{a i r, 22} \cdot s_{a i r, 22}$

The exergy balance equation (ExBE) of wind turbine can be expressed as follows:

$\dot{m}_{\text {air }, 15 \cdot}\left(\boldsymbol{e x}_{\text {air }, 15}+\frac{v_{15}^{2}}{2}\right)=\dot{m}_{a i r, 22} \cdot\left(e x_{a i r, 22}+\frac{v_{22}^{2}}{2}\right)+$

$\dot{W}_{W T}+\dot{E} x_{d, W T}$

The energy and exergy efficiencies of wind turbine are written as follows:

$\eta_{e n_{W T}}=\eta_{e x_{W T}}=\frac{\dot{W}_{W T}}{\dot{m}_{15}\left(\frac{v_{1}^{2}}{2}\right)}$

The transmission and generator efficiencies are considered to be $95 \%$, while AC/DC conversion efficiency is taken as $90 \%$. Using an average windy period of 13 hours, the total energy generated from the wind turbine is calculated:

$W_{\text {wind }_{\text {energy }}}=\dot{W}_{\text {wind }_{\text {electrical }}{ }_{17}}$ time $_{\text {wind }}$

\section{Concentrated PV}

The solar irradiation on the CPV unit is mainly converted into two energy forms; electricity and heat. The generated heat is non-useful in this case, hence considered as loss.

The energy balance equation (EBE) of concentrated PV unit can be expressed as follows:

$\dot{Q}_{C P V, 16}=\dot{W}_{C P V, 12}+\dot{Q}_{\text {loss }, C P V}$

(33) where $\dot{Q}_{C \boldsymbol{P V}, \mathbf{1 6}}=\boldsymbol{A}_{\boldsymbol{C P V}} \boldsymbol{I}_{\text {solar }}$ in $\mathrm{kW}$.

Note that the average irradiance is taken as $0.8 \mathrm{~kW} / \mathrm{m}^{2}$ and the allocated CPV area is $1000 \mathrm{~m}^{2}$. The operation temperature of CPV is taken as $90^{\circ} \mathrm{C}$.

The entropy balance equation (EnBE) of concentrated PV unit can be expressed as follows:

$\frac{\dot{Q}_{C P V, 16}}{T_{s u n}}+\dot{S}_{g e n, C P V}=\frac{\dot{Q}_{\text {loss }, C P V}}{T_{b}}$

The exergy balance equation (ExBE) of concentrated PV unit can be expressed as follows:

$\dot{Q}_{C P V, 16}\left(1-\frac{T_{0}}{T_{s u n}}\right)=\dot{W}_{C P V, 12}+\dot{Q}_{\text {loss }, C P V}\left(1-\frac{T_{0}}{T_{b}}\right)+$

Ex $x_{d, C P V}$

Here, the boundary temperature of heat transfer is calculated using the average of ambient and operating temperature as follows:

$T_{b}=\frac{\left(T_{C P V}+T_{0}\right)}{2}$

Alternatively, the exergy destruction at the CPV unit can also be calculated using:

$\dot{E x}_{d, C P V}=T_{0} \dot{S}_{g e n, C P V}$

The energy efficiency of concentrated PV is written as follows:

$\eta_{e n_{C P V}}=\frac{\dot{W}_{C P V, 12}}{\dot{Q}_{C P V, 16}}$

Note that the electrical efficiency of the CPV is taken as $35 \%$ based on the commercially available units.

The exergy efficiency of concentrated PV is written as follows:

$\eta_{\text {ex }}=\frac{\dot{W}_{C P V}, 12}{\dot{Q}_{C P V, 16}\left(1-\frac{T_{0}}{T_{\text {sun }}}\right)}$

Considering 8 hours of sunshine on average, the daily energy production is calculated from $\mathrm{CPV}$ as follows:

$W_{C P V_{\text {Energy }}}=\dot{W}_{C P V_{12}}$ time $_{\text {sunny }}$

\section{Charging Station}

The total power produced in the charging station is calculated using the summation of the subsystems and efficiency of the charging station:

$$
\begin{aligned}
& \dot{W}_{C S_{14}}=\eta_{C S}\left(\dot{W}_{N_{3} H_{3} C_{11}}+\dot{W}_{H_{2} F C_{10}}+\dot{W}_{C P V_{12}}+\right. \\
& \left.\dot{W}_{\text {wind }_{\text {electrical }}{ }_{17}}\right)
\end{aligned}
$$

Similarly, the total energy generated in the charging station is calculated as follows:

$W_{\text {total }_{\text {CS }} \text { Daily }}=W_{\mathrm{NH}_{3} \mathrm{FC}_{\text {Energy }}}+W_{\mathrm{H}_{2} \mathrm{FC}_{\text {Energy }}}+$
$W_{\text {wind }_{\text {energy }}}+W_{C P V_{\text {Energy }}}$

The number of EVs that can be charged via the designed 
charging station is determined using the total energy produced and the capacity of EV battery:

Number $_{\text {EV }_{\text {Daily }} \text { Charged }}=\frac{w_{\text {total }_{\text {CS }} \text { Daily }_{\text {Energy }}}}{W_{\text {single }_{\text {EV }}} \text { battery }}$

where the capacity of a single-vehicle battery is taken as $50 \mathrm{kWh}$.

The overall energy efficiency of the designed green electric vehicle charging station is calculated as follows:

$\eta_{\text {en } O V E R A L L}=\frac{\dot{W}_{C S_{14}}}{\dot{Q}_{C P V_{16}}+\dot{W}_{\text {wind } 15}+\dot{m}_{1} h_{1}+\dot{m}_{2} h_{2}+\dot{m}_{3} h_{3}}$

Similarly, the overall exergy efficiency is calculated using the following formula:

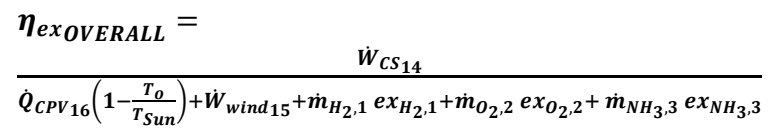

\section{Results and discussion}

The thermodynamic properties of each state point including the mass flow rate, temperature, pressure, specific enthalpy, specific entropy, and specific exergy are tabulated in Table 1. Note that the enthalpy and exergy values account for the chemical energy content of the fuels.

The performance of each subsystem is determined using the efficiency equations given in the analysis section, for which the results are depicted in Fig. 2. The storage efficiencies of ammonia are higher than hydrogen and oxygen gases because ammonia is stored in liquid form rather than gaseous form. This enables a longer-term storage with less losses. $\mathrm{H}_{2}$ and $\mathrm{NH}_{3}$ fuel cell exergy efficiencies are calculated as $78 \%$ and $74 \%$, respectively. The overall system energy and exergy efficiencies are found to be $51.9 \%$ and $52.1 \%$. These values show that the integrated system can perform better compared to a single wind turbine or single CPV systems. Exergy destruction is another measure of inefficiency in the subsystems, for which the values are given in Fig. 3. The highest exergy destruction rate occurs in CPV (about $430 \mathrm{~kW}$ ) due to low electrical efficiency and high solar energy input.

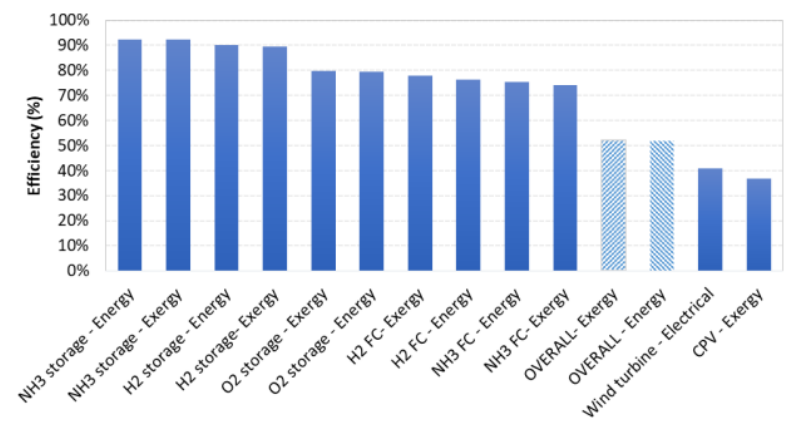

Fig. 2. The energy and exergy efficiencies of the subsystems and overall system
Table 1. Thermodynamic properties of the state points within the complete system

\begin{tabular}{|c|c|c|c|c|c|c|c|}
\hline 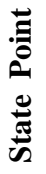 & 离 & $\begin{array}{l}\frac{0}{30} \\
\stackrel{30}{=} \\
\equiv\end{array}$ & $\underbrace{0}_{=}$ & $\begin{array}{l}\underset{\theta}{\theta} \\
0\end{array}$ & 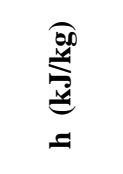 & 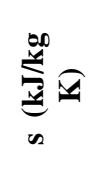 & 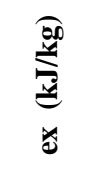 \\
\hline 0 & Air & & 25 & 101.3 & 298.4 & 6.859 & \\
\hline 0 & $\mathrm{H}_{2}$ & & 25 & 101.3 & 3932 & 53.37 & \\
\hline 0 & $\mathrm{O}_{2}$ & & 25 & 101.3 & $\begin{array}{c}0.00006 \\
716\end{array}$ & $\begin{array}{c}0.0000 \\
6428\end{array}$ & \\
\hline 0 & $\mathrm{~N}_{2}$ & & 25 & 101.3 & 309.3 & 6.835 & \\
\hline 0 & $\mathrm{NH}_{3}$ & & 25 & 101.3 & 1547 & 6.602 & \\
\hline 0 & $\mathrm{H}_{2} \mathrm{O}$ & & 25 & 101.3 & 104.9 & 0.3672 & \\
\hline 1 & $\mathrm{H}_{2}$ & 0.005 & 20 & 1500 & 123866 & 42 & $\begin{array}{c}12043 \\
3\end{array}$ \\
\hline 2 & $\mathrm{O}_{2}$ & 0.07303 & 20 & 1500 & -8.156 & $\begin{array}{c}-0.725 \\
4\end{array}$ & 208.1 \\
\hline 3 & $\mathrm{NH}_{3}$ & 0.025 & 20 & 1500 & 18894 & 1.326 & 20161 \\
\hline 4 & $\mathrm{H}_{2}$ & 0.0045 & 20 & 1000 & 123864 & 43.68 & $\begin{array}{c}11993 \\
1\end{array}$ \\
\hline 5 & $\mathrm{O}_{2}$ & 0.036 & 20 & 1000 & -6.884 & $\begin{array}{c}-0.616 \\
6 \\
\end{array}$ & 177 \\
\hline 6 & $\mathrm{O}_{2}$ & 0.03265 & 20 & 1000 & -6.884 & $\begin{array}{c}-0.616 \\
6 \\
\end{array}$ & 177 \\
\hline 7 & $\mathrm{NH}_{3}$ & 0.02313 & 25 & 1000 & 20084 & 5.321 & 20160 \\
\hline 8 & $\mathrm{~N}_{2}$ & 0.01904 & 25 & 1000 & 307.3 & 6.15 & 228.2 \\
\hline 9 & $\mathrm{H}_{2} \mathrm{O}$ & 0.0405 & 25 & 1000 & 105.8 & 0.367 & 50.86 \\
\hline 15 & Air & 4170 & 25 & 101.3 & 298.4 & 6.859 & 0 \\
\hline 18 & $\mathrm{H}_{2}$ & 0.0005 & 25 & 101.3 & 123932 & 53.38 & $\begin{array}{c}11710 \\
8 \\
\end{array}$ \\
\hline 19 & $\mathrm{NH}_{3}$ & 0.001875 & 25 & 101.3 & 20147 & 6.602 & 19841 \\
\hline 20 & $\mathrm{O}_{2}$ & 0.004382 & 25 & 101.3 & $\begin{array}{c}0.00006 \\
716 \\
\end{array}$ & $\begin{array}{c}0.0000 \\
6428 \\
\end{array}$ & 0 \\
\hline 21 & $\mathrm{H}_{2} \mathrm{O}$ & 0.03673 & 25 & 1000 & 105.8 & 0.367 & 50.86 \\
\hline 22 & Air & 4170 & 25 & 101.3 & 298.4 & 6.859 & 0 \\
\hline 23 & $\mathrm{NH}_{3}$ & 0.02313 & 20 & 1000 & 18894 & 1.328 & 20160 \\
\hline
\end{tabular}

The $\mathrm{NH}_{3}$ and $\mathrm{H}_{2}$ fuel cells bear exergy destruction rates of $116.2 \mathrm{~kW}$ and $119.8 \mathrm{~kW}$, respectively. As expected, $\mathrm{NH}_{3}$ storage yields lower exergy destruction because of liquidphase storage. This result further emphasizes the importance of $\mathrm{NH}_{3}$ storage systems to be used in the EV/PHEV charging stations with considerably fewer losses and higher efficiencies. This becomes more obvious when the volumetric capacities of the storage tanks are considered as shown in Table 2 . When ammonia is stored in liquid form, the density reduces almost 80 times, which enables significantly less volume requirement $\left(2.83 \mathrm{~m}^{3}\right)$. On the other hand, $\mathrm{H}_{2}$ and $\mathrm{O}_{2}$ require about $281 \mathrm{~m}^{3}$ and 253 $\mathrm{m}^{3}$ volume storage tanks, respectively. This can be further elaborated on the optimization of the area due to limited space in the charging stations. 


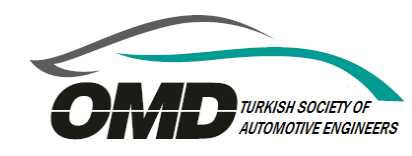

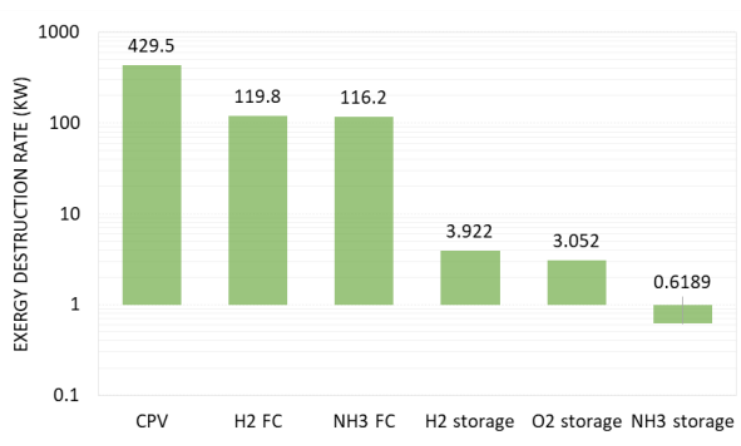

Fig. 3. The exergy destruction rates of the subsystems

Table 2. The volumetric capacities of the storage tanks

\begin{tabular}{c|c} 
Storage Medium & Volume $\left(\mathbf{m}^{\mathbf{3}}\right)$ \\
\hline $\mathrm{H}_{2}$ Storage & 281.1 \\
\hline $\mathrm{NH}_{3}$ Storage & 2.83 \\
\hline $\mathrm{O}_{2}$ Storage & 253.7
\end{tabular}

Similar to exergy destruction, entropy generation rates represent the creation of entropy due to the irreversibility of the processes as the obtained values are listed in Table 3 for the subsystems.

Table 3. The entropy generation rates of the subsystems

\begin{tabular}{c|c} 
Subsystem & Entropy generation rate $(\mathbf{k W} / \mathbf{K})$ \\
\hline $\mathrm{CPV}$ & 1.44 \\
\hline $\mathrm{H}_{2}$ FC & 0.272 \\
\hline $\mathrm{H}_{2}$ Storage & 0.01323 \\
\hline $\mathrm{NH}_{3}$ FC & 0.3794 \\
\hline $\mathrm{NH}_{3}$ storage & 0.009935 \\
\hline $\mathrm{O}_{2}$ storage & 0.01065
\end{tabular}

The final end product in an EV/PHEV charging station is the produced electricity. The power production from each subsystem is shown in Table 4, where $\mathrm{H}_{2}$ and $\mathrm{NH}_{3}$ fuel cells contribute with $425 \mathrm{~kW}$ and $350 \mathrm{~kW}$ electricity. The selected wind turbine capacity is small due to limitations in a city center to place the wind turbine. However, it is important to compensate for the non-availability of the sunshine during night time. CPV is capable of producing about $280 \mathrm{~kW}$. In total, the charging station produces about 1.1 MW power. Based on the operating hours, sunny hours and windy hours, the energy generation from each subsystem is depicted in Table 5. In total, about 15.46 MWh of electricity is generated daily, which can charge about 309 EVs. From Table 5, it can be deduced that CPV contributes to about $14.4 \%$, and fuel cells generate about $80 \%$ of energy in a day. Here, it is important to note that the fuels $\left(\mathrm{H}_{2}\right.$ and $\left.\mathrm{NH}_{3}\right)$ and oxidant $\left(\mathrm{O}_{2}\right)$ are transported to the charging station, which brings additional energy consumption through truck tankers or pipelines.
Table 4. Power production from the wind turbine, CPV and fuel cells

\begin{tabular}{c|c} 
Subsystem & Power production $(\mathbf{k W})$ \\
\hline $\mathrm{CPV}$ & 280 \\
\hline $\mathrm{H}_{2} \mathrm{FC}$ & 425.3 \\
\hline $\mathrm{NH}_{3} \mathrm{FC}$ & 349.6 \\
\hline Wind turbine & 63.73 \\
\hline Charging station (total) & 1119
\end{tabular}

Table 5. Daily energy production from the wind turbine, CPV and fuel cells

\begin{tabular}{c|c} 
Subsystem & $\begin{array}{c}\text { Daily energy production } \\
\text { (kWh/day) }\end{array}$ \\
\hline $\mathrm{CPV}$ & 2240 \\
\hline $\mathrm{H}_{2} \mathrm{FC}$ & 6804 \\
\hline $\mathrm{NH}_{3} \mathrm{FC}$ & 5594 \\
\hline Wind turbine & 828.5 \\
\hline Charging station (total) & 15466
\end{tabular}

\section{Parametric Studies}

Since solar irradiance, wind speed and fuel feed rates are the main inputs to the charging station, their effects are investigated through parametric analysis. Fig. 4 illustrates the changes in the efficiency, power, and exergy destruction rate based on the solar irradiance available at that moment. Note that the initial design considers $800 \mathrm{~W} / \mathrm{m}^{2}$ solar irradiance. However, since the irradiance changes during the day, the produced power, as well as the performance, is affected. Although the power production increases from the CPV unit with increasing irradiance, the overall exergy efficiency reduces from $56.1 \%$ to $52.1 \%$ due to the fact that the exergy destruction increases more drastically compared to power output.

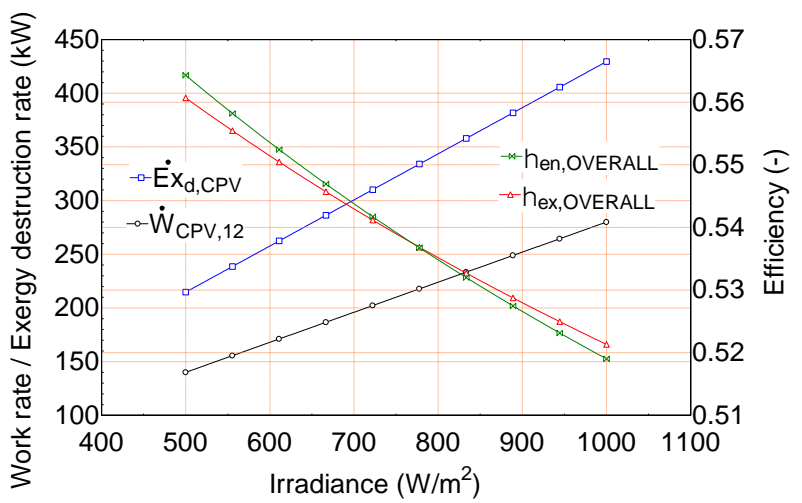

Fig. 4. The effects of solar irradiance on the overall system efficiencies, power production from $\mathrm{CPV}$ and exergy destruction of CPV

On the other hand, since daily energy generation from $\mathrm{CPV}$ unit rises with the higher solar irradiance, the total energy generated in the charging station increases from 
$14346 \mathrm{kWh}$ to $15466 \mathrm{kWh}$ (from $500 \mathrm{~W} / \mathrm{m}^{2}$ to 1000 $\mathrm{W} / \mathrm{m}^{2}$ ), which increases the number of charged vehicles to 309 as illustrated in Fig. 5. Note that at the initial design conditions, $300 \mathrm{EVs}$ can be charged.

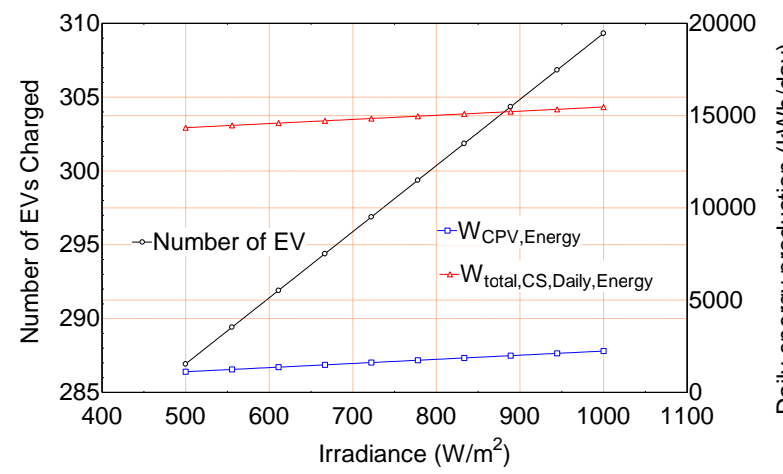

Fig. 5. The effects of solar irradiance on the total daily energy generation, CPV energy generation and number of EVs charged in a day

The higher is the wind speed, the higher is the produced power from the wind turbine as depicted in Fig. 6. However, the overall exergy efficiency of the system declines from $53.0 \%$ to $49.9 \%$ when the wind speed increases from 4 to $10 \mathrm{~m} / \mathrm{s}$ as shown in Fig. 6. This is attributed to the kinetic energy input from the wind is expected to be greater to increase the power output, where the electrical efficiency of the wind turbine is about $40.7 \%$, which is lower than the overall system efficiency.

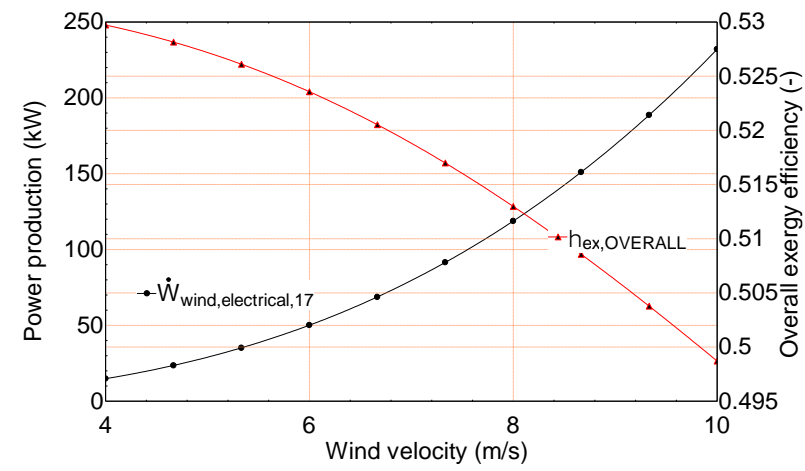

Fig. 6. The effects of wind speed on the power production from the wind turbine and overall exergy efficiency

With the increasing energy generation from the wind turbine, at $10 \mathrm{~m} / \mathrm{s}$, the number of EVs that can be charged rises to 353 as depicted in Fig. 7. This shows that the locations with higher average wind speed will generate more electricity required for the EV charging station. Note that at the initial design conditions, the wind speed is taken as $6.5 \mathrm{~m} / \mathrm{s}$ with a windy hours of 13 .

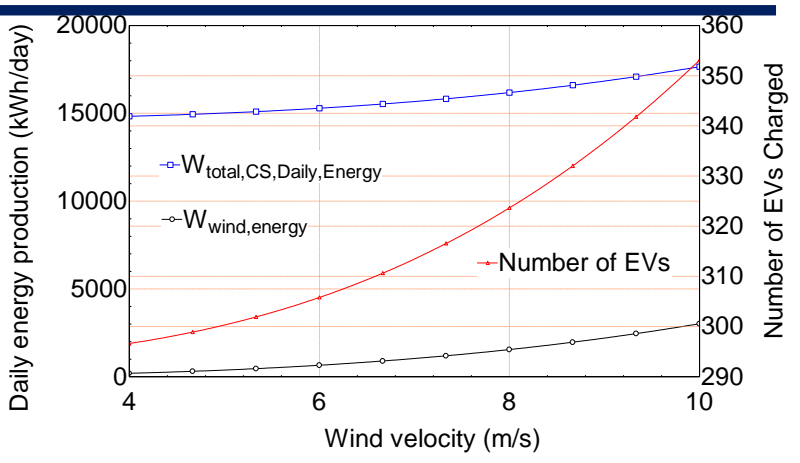

Fig. 7. The effects of wind speed on the daily energy generation from the wind turbine and total energy generation in a day

The fuels supplied from the storage tanks are also quite critical in the overall system performance and total energy generation. Fig. 8 illustrates the changes in the $\mathrm{H}_{2}$ fuel cell performance versus the hydrogen supply. The storage unit has very minor exergy destruction compared to the fuel cell. When the hydrogen supply increases from $1 \mathrm{~g} / \mathrm{s}$ to 8 $\mathrm{g} / \mathrm{s}$, the power generated from $\mathrm{H}_{2}$ fuel cell rises to $680 \mathrm{~kW}$. This translates into a larger number of EVs to be charged, corresponding to about 391 EVs as shown in Fig. 9. This causes the overall exergy efficiency to rise because the $\mathrm{H}_{2}$ fuel cell operates at significantly higher exergy efficiency (77.9\%) than the complete system. However, there are limitations due to the volumetric capacity of the $\mathrm{H}_{2}$ storage tanks, which enlarges drastically from $56 \mathrm{~m}^{3}$ to $449 \mathrm{~m}^{3}$ as shown in Fig. 9. This is because of the low energy density of gaseous hydrogen. The energy generated from the $\mathrm{H}_{2}$ fuel cell reaches $10887 \mathrm{kWh}$ per day at $8 \mathrm{~g} / \mathrm{s}$ feed rate.

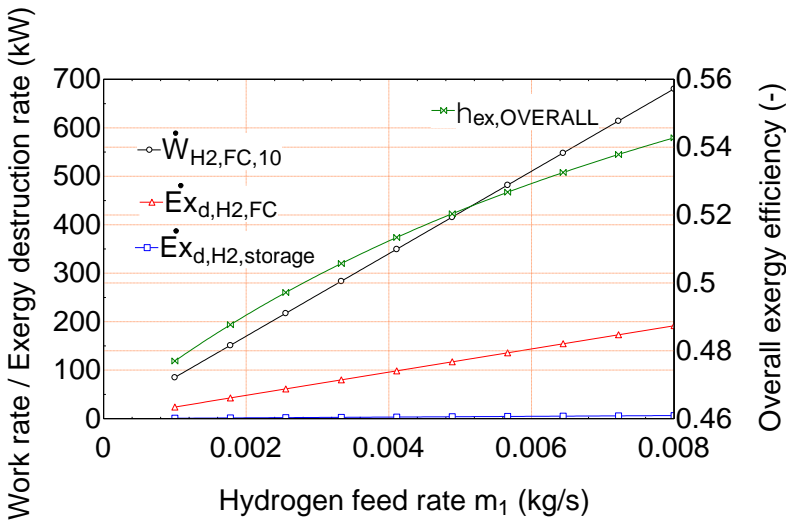

Fig. 8. The effects of hydrogen feed rate to the storage tank on the power production from the $\mathrm{H}_{2}$ fuel cell, exergy destruction of the $\mathrm{H}_{2}$ fuel cell and overall exergy efficiency 


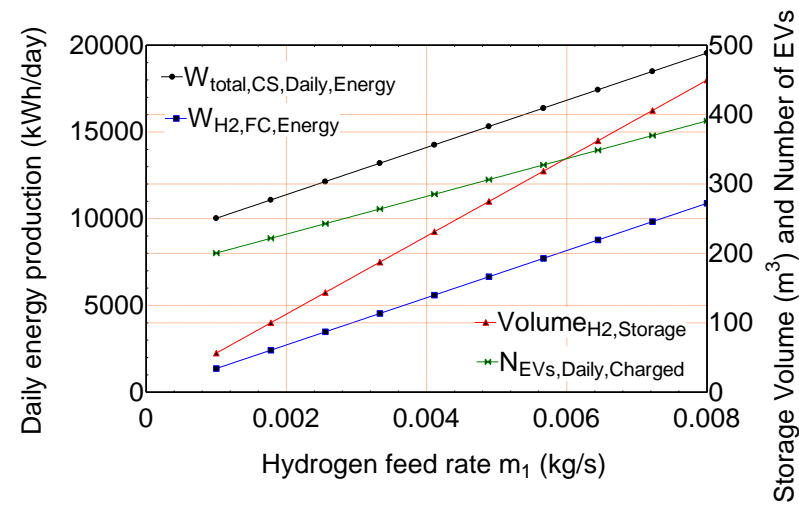

Fig. 9. The effects of hydrogen feed rate to the storage tank on the daily energy production, the volumetric capacity of the storage tank and number of EVs charged in a day

Similarly, the ammonia feed rate plays a critical role in the overall performance as shown in Fig. 10. The exergy efficiency of the overall system can reach $57.6 \%$ at an $\mathrm{NH}_{3}$ feed rate of $0.1 \mathrm{~kg} / \mathrm{s}$. The exergy destruction of $\mathrm{NH}_{3}$ storage is very low compared to $\mathrm{H}_{2}$ or $\mathrm{O}_{2}$ storage. Note that the system is initially designed to operate at $0.025 \mathrm{~kg} / \mathrm{s}$ of ammonia feed rate. However, in case it rises to $0.1 \mathrm{~kg} / \mathrm{s}$, the number of EVs to be charged can reach 644 with an $\mathrm{NH}_{3}$ fuel cell power output of 1.4 MW as illustrated in Fig. 11. This can be optimization criteria when the size of the storage tanks and the medium/long term mass losses are further considered.

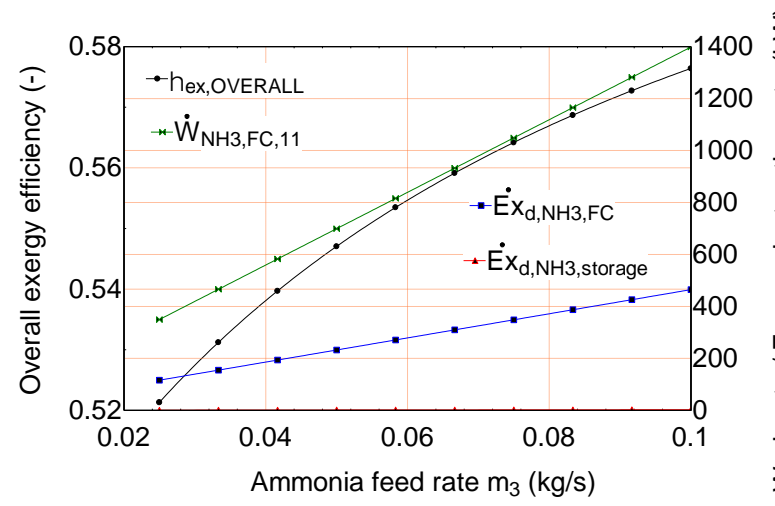

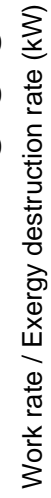

Fig. 10. The effects of ammonia feed rate to the storage tank on the power production from the $\mathrm{NH}_{3}$ fuel cell, exergy destruction of the $\mathrm{NH}_{3}$ fuel cell and storage, and overall exergy efficiency

The designed EV charging station is capable of producing on-site electricity independent from the grid, which can charge up to $644 \mathrm{EVs}$ at an $\mathrm{NH}_{3}$ feed rate of $0.1 \mathrm{~kg} / \mathrm{s}$. This type of system will be important especially for rural areas or outside city centers, where the area limitations are not anticipated.

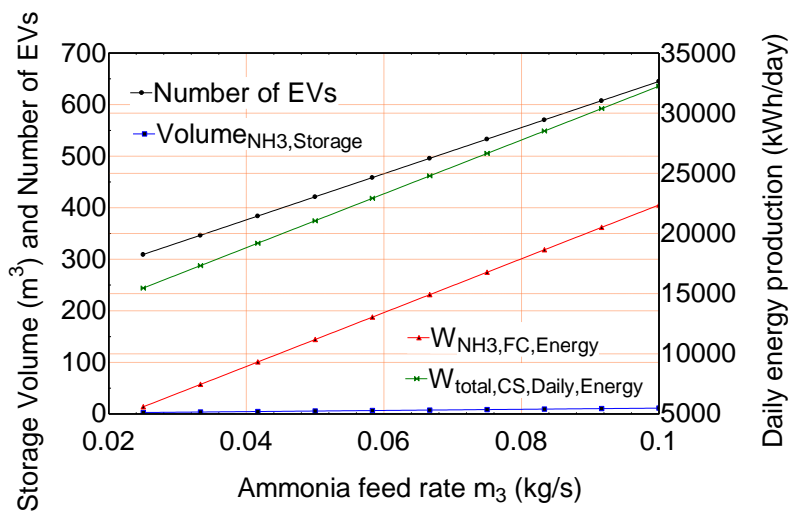

Fig. 11. The effects of ammonia feed rate to the storage tank on the daily energy production, the volumetric capacity of the storage tank and the number of EVs charged in a day

\section{Conclusions}

This study presents a self-power generating EV/PHEV charging station with $\mathrm{H}_{2}$ and $\mathrm{NH}_{3}$ fuel cells as well as CPV units and wind turbines. The CPVs are considered for EV/PHEV charging stations because of requiring less area compared to PVs, and this is one of the main design criteria in limited space charging stations. The overall system efficiencies are greater than the wind turbine and CPV efficiencies, which translates into a better and more sustainable charging station. The use of two different fuel cell enables a more diverse electricity generation route with the advantage of flexible storage. In most of the cases, $\mathrm{H}_{2}$ can serve as a short-term storage, whereas $\mathrm{NH}_{3}$ can serve as a medium/long term storage with more convenient storage characteristics. The main contribution of energy generated comes from the fuel cell corresponding to about $80 \%$. The system can be further optimized considering the storage capacities, storage time, and number of EVs to be charged.

\section{Acknowledgment}

The authors acknowledge the great support provided by Hamad Bin Khalifa University, Qatar.

\section{Nomenclature}

$\begin{array}{ll}\mathrm{A} & \text { Area of wind turbine, } \mathrm{m}^{2} \\ \dot{\boldsymbol{E}} \boldsymbol{x}_{\boldsymbol{d}} & \text { Exergy destruction rate, } \mathrm{kW} \\ \mathrm{ex} & \text { Specific exergy, } \mathrm{kJ} / \mathrm{kg} \\ \mathrm{h} & \text { Specific enthalpy, } \mathrm{kJ} / \mathrm{kg} \\ \dot{\mathbf{m}} & \text { Mass flow rate, } \mathrm{kg} / \mathrm{s} \\ \mathrm{P} & \text { Pressure, } \mathrm{kPa} \\ \dot{\mathbf{Q}} & \text { Heat flow rate, } \mathrm{kW} \\ \mathrm{s} & \text { Specific entropy, } \mathrm{kJ} / \mathrm{kg}-\mathrm{K} \\ \dot{\boldsymbol{S}}_{\boldsymbol{g} \text { en }} & \text { Entropy generation rate, } \mathrm{kW} / \mathrm{K} \\ \mathrm{T} & \text { Temperature, }{ }^{\circ} \mathrm{C} \text { or K } \\ \mathrm{V} & \text { Velocity, } \mathrm{m} / \mathrm{s} \\ \mathrm{W} & \text { Work, } \mathrm{kJ} \text { or } \mathrm{kWh} \\ \dot{\mathbf{W}} & \text { Work rate, } \mathrm{kW}\end{array}$




\begin{tabular}{ll}
\hline Acronyms & \\
CPV & Concentrated photovoltaic \\
CS & Charging station \\
EBE & Energy balance equation \\
EnBE & Entropy balance equation \\
ExBE & Exergy balance equation \\
EV & Electric vehicle \\
FC & Fuel cell \\
GHG & Greenhouse gas \\
LHV & Lower heating value \\
MBE & Mass balance equation \\
PHEV & Plug-in hybrid electric vehicle \\
WT & Wind turbine \\
Subscripts & \\
0 & Reference state \\
b & Boundary \\
CS & Charging station \\
en & Energy \\
ex & Exergy \\
EV & Electric vehicle \\
WT & Wind turbine \\
Greek letters & \\
$\rho$ & Density of air \\
$\boldsymbol{\eta}$ & Efficiency
\end{tabular}

\section{References}

[1] Bicer Y, Dincer I. (2018). Life cycle environmental impact assessments and comparisons of alternative fuels for clean vehicles. Resour Conserv Recycl. doi:10.1016/j.resconrec.2018.01.036.

[2] Girard A, Roberts C, Simon F, Ordoñez J. (2018).Solar electricity production and taxi electrical vehicle conversion in Chile. J Clean Prod 2019;210:1261-9. doi:10.1016/j.jclepro.11.092.

[3] Ghenai C, Bettayeb M. (2019). Modelling and performance analysis of a stand-alone hybrid solar PV/Fuel Cell/Diesel Generator power system for university building. Energy;171:180-9. doi:10.1016/j.energy.2019.01.019.

[4] Mozafar MR, Moradi MH, Amini MH. (2017). A simultaneous approach for optimal allocation of renewable energy sources and electric vehicle charging stations in smart grids based on improved GA-PSO algorithm. Sustain Cities Soc ;32:627-37. doi:10.1016/J.SCS.2017.05.007.

[5] Amjad M, Ahmad A, Rehmani MH, Umer T. (2018).A review of EVs charging: From the perspective of energy optimization, optimization approaches, and charging techniques. Transp Res Part D Transp Environ ;62:386-417. doi:10.1016/j.trd.2018.03.006.

[6] Fazelpour F, Vafaeipour M, Rahbari O, Rosen MA. (2014). Intelligent optimization to integrate a plug-in hybrid electric vehicle smart parking lot with renewable energy resources and enhance grid characteristics. Energy Convers Manag;77:250-61. doi:10.1016/j.enconman.2013.09.006.

[7] Karmaker AK, Ahmed MR, Hossain MA, Sikder MM. (2018). Feasibility assessment \& design of hybrid renewable energy based electric vehicle charging station in Bangladesh. Sustain Cities Soc;39:189-202. doi:10.1016/j.scs.2018.02.035.
[8] Grande LSA, Yahyaoui I, Gómez SA. (2018). Energetic, economic and environmental viability of off-grid PV-BESS for charging electric vehicles: Case study of Spain. Sustain Cities Soc;37:519-29. doi:10.1016/J.SCS.2017.12.009.

[9] Dicks G, Breedon F.(2013). World Outlook. vol. 12. 2013th ed. International Energy Agency (IEA); 1988. doi:10.1111/j.1468-0319.1988.tb00400.x.

[10] García-Villalobos J, Zamora I, San Martín JI, Asensio FJ, Aperribay V. (2014). Plug-in electric vehicles in electric distribution networks: A review of smart charging approaches. Renew Sustain Energy Rev;38:717-31. doi:10.1016/j.rser.2014.07.040.

[11] Amini MH, Boroojeni KG, Cheng Jian Wang, Nejadpak A, Iyengar SS, Karabasoglu O. (2016). Effect of electric vehicle parking lots' charging demand as dispatchable loads on power systems loss. 2016 IEEE Int. Conf. Electro Inf. Technol., IEEE; p. 0499-503. doi:10.1109/EIT.2016.7535291.

[12] Zhang Y, He Y, Wang X, Wang Y, Fang C, Xue H, et al. (2019). Modeling of fast charging station equipped with energy storage. Glob Energy Interconnect;1:145-52. doi:.1037//00332909.I26.1.78.

[13] Razipour R, Moghaddas-Tafreshi SM, Farhadi P. (2019). Optimal management of electric vehicles in an intelligent parking lot in the presence of hydrogen storage system. J Energy Storage;22:144-52. doi:10.1016/j.est.2019.02.001.

[14] Wu D, Radhakrishnan N, Huang S. (2019). A hierarchical charging control of plug-in electric vehicles with simple flexibility model. Appl Energy;253:113490. doi:10.1016/j.apenergy.2019.113490.

[15] Goli P, Shireen W. (2014). PV powered smart charging station for PHEVs. Renew Energy;66:280-7. doi:10.1016/j.renene.2013.11.066.

[16] Caliskan H, Dincer I, Hepbasli A. (2013). Exergoeconomic and environmental impact analyses of a renewable energy based hydrogen production system. Int J Hydrogen Energy;38:610411. doi:10.1016/j.ijhydene.2013.01.069.

[17] Ramadhani F, Hussain MA, Mokhlis H, Fazly M, Ali JM. (2019). Evaluation of solid oxide fuel cell based polygeneration system in residential areas integrating with electric charging and hydrogen fueling stations for vehicles. Appl Energy;238:137388. doi:10.1016/j.apenergy.2019.01.150.

[18] Rabbani M, Dincer I, Naterer GF. (2012). Thermodynamic assessment of a wind turbine based combined cycle. Energy ;44:321-8. doi:10.1016/j.energy.2012.06.027.

[19] Caduff M, Huijbregts MAJ, Althaus H-J, Koehler A, Hellweg S. (2012). Wind power electricity: the bigger the turbine, the greener the electricity? Environ Sci Technol;46:4725-33. doi:10.1021/es204108n.

[20] Notton G. (2010). Hybrid wind-photovoltaic energy systems. Stand-Alone Hybrid Wind Energy Systems, Elsevier;, p. 216-53. doi:10.1533/9781845699628.2.216. 
[21] Software F-C, Software. (2018). Engineering Equations Solver.

[22] Andersson J, Grönkvist S. (2019). Large-scale storage of hydrogen. Int $J$ Hydrogen Energy;44:11901-19. doi:10.1016/j.ijhydene.2019.03.063.

[23] Ahluwalia RK, Peng J-K, Hua TQ. (2016). Cryocompressed hydrogen storage. Compend. Hydrog. Energy, Elsevier; p. 119-45. doi:10.1016/b978-1-78242-362-1.00005-5.

[24] Rivard E, Trudeau M, Zaghib K. (2019).Hydrogen Storage for Mobility: A Review. Materials (Basel);12:1973. doi:10.3390/ma12121973.

[25] U.S. DRIVE. (2017).Hydrogen Storage Technologies Roadmap.. 